\title{
Mandatory Pension System and Redistribution: The Comparative Analysis of Institutions in Baltic States
}

\begin{abstract}
Mandatory pension systems occupy a central role in the system of social security because of the share of social expenditure in national economies. One of the goals of pension system is to redistribute incomes among individuals. However, it is not clear how the intentions to redistribute incomes coincide with the outcomes. In this paper, we will study the difference between the intentions as they are articulated within institutions, with the outcomes that are generated by them. We use the method of comparative institutional analysis in order to find out the differences. Our comparative institutional analysis is based on the grammar of institutions that is proposed by Crawford and Ostrom. Also, in order to understand the differences, we will compare the institutions in relatively similar cases - the Baltic States. The results show that there is a gap between the intentions and outcomes to redistribute incomes among individuals. The findings from the comparative institutional analysis suggest that the most redistributive old age pension system is in Estonia. However, according to the factual information from Eurostat, the greatest distributive effect is produced by the mandatory pension system of Lithuania.
\end{abstract}

KEYWORDS: Redistribution, Mandatory pension system, Institutions, Comparative analysis, Baltic States

RECEIVED 7 July 2016; ACCEPTED 2 October 2016.

\section{INTRODUCTION}

Social world is complex and the impact of various factors is unknown and unpredictable, therefore, there is a high degree of uncertainty and collective decisions are the instruments to cope with it. The results of political and administrative decisions are institutions - the rules of the game for individual and collective agents. According to Crawford and Ostrom (1995), there are at least three types of institutions: rules, norms and strategies. All institutions govern the actions of various actors. However, there is a difference in the way they do it. Strategies express what an actor has, must, can or is forbidden to do. Norms have additional elements 'Conditions', which specify what an actor has, must, can or is forbidden to do. There is one more element in rules - 'Sanction' - what will happen if an actor obeys. But there is a problem - due to the impact of various factors, the institutions do not perform as it was planned. The outcomes that are generated by certain institutional structures quite often are not the same as it was intended. The clash between political intentions and outcomes is well documented in various studies. ${ }^{2}$ In order to identify the clash, we have to compare the hypothetical outcome that was in the minds of institutional architects with the factual. But there are some obstacles. Firstly, it is hard to obtain the accurate information about the intentions of the architects. Secondly, it is hard (or even impossible) to find the 'right' intention, as there are a lot of intentions representing different interests. Thirdly, there is a room for interpretation of institutions because of their linguistic nature.

Pension systems occupy a central role in the system of social security, because of the share of social resources in national economies. Public pensions are often the largest single item of government expenditure, accounting for $17 \%$ of the total government spending on average (Pensions at a glance 2011, p. 154). The main goal of pension system is to make the incomes smooth throughout the life span. However, there are other goals. One of them is the prevention of poverty in old age. Broadly speaking, the goal of pension

1 Eugenijus Dunajevas, Daiva Skučienè: Vilniaus Universitetas, Lithuania. Email: eugenijus.dunajevas@fsf.vu.lt; daiva.skuciene@fsf.vu.lt.

2 The problem is important in various policy fields: in telecommunications (Gillwald, 2005), in fertility (Philipov, 2009), in education (Cranmer, 2006) and forest policy (Clement \& Amezaga, 2009). 
system is to redistribute incomes, but in one case, it is the redistribution for an individual and in another case, it is the redistribution between individuals.

In this study, we will compare the pension systems of the Baltic States with respect to their redistributive intentions and outcomes. There are comparative studies of pension systems in the Baltic States, but they analyse different aspects. For example, Müller (2002) and Casey (2004) compared the reforms of pension systems. Pension benefits were compared in the study of Whitehouse (2004). Aidukaite (2006) analysed and compared the social security institutions of the Baltic States with respect to eligibility conditions, replacement rates, financing and contributions. The extensive research on redistributive aspects of pension systems in Baltic States is done by Olga Rajevska (2013; 2014 (with Feliciana Rajevska); 2015; 2016). Olga Rajevska compared the pension systems of Estonia and Latvia with respect to the criterion of equity (2014), analysed the results of NDC system in Latvia (2014 with Feliciana Rajevska), studied the sustainability of pension systems in the Baltic States (2015) and compared the replacement rates of old age pension benefits in the Baltic States (2016).

The goal of the paper is to analyse the gap between intentions as they are articulated within the institutions of mandatory pension system, with the outcomes that are generated by the institutions. In order to identify the institutions that generate the difference, we will compare the institutions of mandatory pension system in relatively similar cases - the Baltic States.

The structure of the paper is organised in this way. We will conceptualise the redistributive aspect of mandatory pension system in the first part of the paper. The methodology of comparative institutional analysis will be presented in the second part. The institutional differences will be presented and discussed in the third part.

\section{MANDATORY PENSION SYSTEM IN THE BALTIC STATES}

There are different ways to organize the system of social security and pension system in particular (Pensions at a glance, 2011). Therefore, it is common to talk about the pension systems and not the pension system. However, the concept of system suggests that there are different systems because of the different number and configuration of elements.

According to Matttil (2006), the basic element of a pension system is public pension. In alternative taxonomy, it is called the first tier or pillar of pension system (Pensions at a glance, 2011) or social insurance. The public pension system is organized by the principle pay as you go. The participation is mandatory in the system. Public administrators are responsible for the organisation and administration of the system. Also, the system covers additional risks apart from old age, such as disability and the loss of earner (survivors). The goal of public pension system is to provide the basic security against the loss of incomes. The other element of pension system is an occupational or personal pension. Also, this element of pension system is called second tier or pillar. Usually, participation is obligatory for the inhabitants. The element works by the principle of funding. The goal is to smooth the incomes of an individual throughout his life span. The occupational or personal pensions are administrated by private organisations. This type of pension became popular in the period from 1981 to 2004. According to Orenstein (2013), the architects of occupational or personal pensions also were seeking to create new pools for capital investment and reduce the state's responsibility. Also, there is a possibility for voluntary insurance. The individuals with high incomes are mostly attracted to the element of voluntary insurance. This element is also called the third tier or pillar of the pension system. The elements public and occupational or personal pensions constitute the mandatory pension system.

According to Matill (2006), the configuration of pension system is determined by various exogenous risk factors - economic, demographic, political and catastrophic factors. Also, the existing configuration of the pension system is path dependent (especially in post-communist countries).

The configuration of contemporary mandatory pension system in the Baltic States was heavily influenced by the legacy of Soviet Union (Lazutka, 2007). The elements of Bismarckian social insurance were established in the Baltic States before the occupation of Soviet Union - in Estonia 1906 and 1924, Latvia 1922 and Lithuania 1922 (Cerami, 2011). However, after the Soviet Occupation, the institutions of social insurance system were expanded. Following the Independence of Baltic States, the pension systems were reformed. In spite of the fact that Baltic States started from an identical institutional legacy (Norkus, 2012), there was some variation in the construction of pensions system (Müller, 2002). However, the contemporary pension systems are quite the same in the Baltic States (Aidukaite, 2006; Cerami, 2011; Orenstein, 2013). The elements of public pension, personal pension and voluntary insurance are in all Baltic States. Also, the old age pension benefits are similar (Table 1). 
Tab. 1: Old age pension benefits (EUR) in the Baltic States in 2014

\begin{tabular}{llccc}
\hline & Variables & Lithuania & Latvia & Estonia \\
\hline A & Average net monthly earnings of employees in the whole economy & 522 & 544 & 769 \\
\hline B & Average net old-age pension & 240.7 & 266.3 & 345.1 \\
\hline & Proportion B/A & 46.1 & 48.9 & 44.9 \\
\hline C & $\begin{array}{l}\text { Mean equivalised net income before social transfers (pensions included in } \\
\text { social transfers) }\end{array}$ & 373.3 & 399.3 & 570.5 \\
\hline & Proportion B/C & 64.5 & 66.7 & 60.5 \\
\hline
\end{tabular}

Source: Author's calculations based on the data from Eurostat (GDP (\%) for old age pensions [] and mean equivalised net income before social transfers [ilc_di13]), Economic and social development in Lithuania, Latvia and Estonia (2015) (average net monthly earning of employees), Central statistical Bureau of Latvia (average old age pension in Latvia), Statistical Yearbook of Estonia (2016) (average old age pension in Estonia) and SODRA (average old age pension Lithuania).

The ratio between average old age pension benefits and average net monthly earnings show that the pension systems in the Baltic States are quite similar. However, the lowest ratio is in Estonia (44.9), while Lithuania comes second (46.1) and the highest ratio is in Latvia (48.9). Also, the ratios between old age pension benefits and the mean income before social transfers confirm the same tendency.

\section{THE GOALS OF PENSION SYSTEM}

Inequality is a common feature of capitalist democracies and there are instruments to cope with it. But before talking about the instruments (and pension system in particularly), it is important to answer the questions that have been raised by Atkinson (2003, p. 481): Inequality of what? Among whom? Measured how? The most popular objects of inequality are wage inequality, wealth inequality and opportunity inequality (Neckerman \& Torche, 2007). In this paper, we are studying the inequality of incomes, among individuals and measured by Gini coefficient. In spite of the popularity of Gini coefficient, it expresses less information about the income distribution at extreme ranges (Lazutka, 2003; Skučienè, 2007).

The pension system is one of the instruments ${ }^{3}$ to cope with the income inequality among individuals. There are at least two dimensions in income inequality (Barr, 1998). The same individual due to the internal and external factors will have different incomes over his or her life span. Also, the incomes are different between young and old, men and women, rich and poor. ${ }^{4}$

The above mentioned inequalities can be affected through the redistributive effect of pension system. But as Barr (1998, p.219) states: The redistribution is not inevitable. It is important to acknowledge that there are differences between advanced and developing welfare states in the redistributive effect of pension systems (Hwang, 2016). The redistributive effect is clear in the advanced welfare states, while the pension systems can reinforce the inequality of incomes in developing welfare states.

3 Income inequality also can be affected by different rates of taxes that inhabitants pay, by different consumption of public services and by different benefits they receive (Reynolds \& Smolensky, 1977).

4 It is a common sense, that the incomes of men are higher than of women, but as it is mentioned by Barr (1998), women also live longer and collect pensions longer. Also, the rich have a longer education and start to pay contributions later. 


\section{INTENTIONS AND OUTCOMES}

The politicians and public administrators have to design the policy in a way that the difference between intentions and outcomes would be minimal or there would be no difference. However, in practice, the policy outcomes are different from intentions, and there are various reasons for it. We think that the causes are inherent in the process of institution construction.

In the first stage, the causes are lack of information and the bargaining nature of politics. Political decisions are the result of bargaining between different interests in democratic societies. When the interests are different, it is impossible to select the best alternative for all. Especially it is hard, when the interests are antagonistic. Moreover, to find out the best political solution, all alternatives and related costs and benefits have to be known. ${ }^{5}$

The second stage is the transformation of intentions into institutional statements. All institutions are inter-connected in some way. The construction of institutions without deep understanding of the whole institutional structure will cause conflicts and unintended negative effects.

At last, the implementation of institutions is complicated. Generally, implementation is not performed by the architects of institutions. The implementation of political decisions largely depends on administrators, who make a lot of decisions in the process of policy implementation. Administrators are driven by different motivations that cause different outcomes (Le Grand, 2003). Also, there are other agents that are not interested in the new institutional structure, and they will look for the opportunities to deviate (Mahoney \& Thelen, 2010).

\section{PENSIONS AND INCOME REDISTRIBUTION}

As it was mentioned before, mandatory pension system redistributes the incomes among individuals in society. The redistributive effect of mandatory pension systems in the Baltic States and EU is shown in Table 2.

Tab. 2: The redistributive effect of mandatory pension systems in EU in 2014

\begin{tabular}{lllll}
\hline Countries & Gini before pensions & Gini after pensions & Difference & Change in \% \\
\hline Estonia & 50,9 & 39,2 & 11,7 & 23,0 \\
\hline Latvia & 50,3 & 38,5 & 11,8 & 23,5 \\
\hline Lithuania & 51,8 & 39,4 & 12,4 & 23,9 \\
\hline EU (28 countries) & 51,8 & 36,5 & 15,3 & 29,5 \\
\hline
\end{tabular}

Source: Author's calculations based on Eurostat data (Tables [ilc_di12b] and [ilc_di12c])

Table 2 shows the changes of Gini coefficient ${ }^{6}$ of equivalised disposable income after pensions. According to Eurostat, the concept of pensions is used to signify the old age and survivors pensions in the calculations of income inequality.

As we can see, the distributive effect of pensions is low in Baltic States in respect to the other EU countries. The average of EU (28 countries) is 29.5 per cent of Gini coefficient change after the pensions. Meanwhile, the change of Gini coefficient after the pensions

5 Cash benefits are used in order to fortify the autonomy of social service clients, and also to enhance the market (Žalimienė \& Dunajevas, 2014). However, cash benefits are also provided to drug abusers. Cash benefits liberalize person and allow him to satisfy need in the best way only if he is rational. Drug abusers are not rational.

6 The Gini coefficient of whole population is not the best measure to compare the redistributive effect of old age pensions, because of the different number of pensioners in the countries. However, there is no data just for pensioners in databases (like Eurostat) that enable to do cross country comparisons. 
is around 23 per cent in Baltic States. The results of distributive effect show the similarity of mandatory pension systems in the Baltic States. But do the architects of mandatory pension systems have had the same ideas, intentions? Do the intentions inherent in the institutional structure of old age pension systems same or different? That are the questions we would like to answer in the second part of the paper.

\section{METHODOLOGY}

The goal of this comparative institutional analysis is to analyse the redistributive effect of mandatory pension systems in the Baltic States. According to Ostrom (2011), institutions are the rules that govern the actions of actors in certain action arenas. Institutions are expressed in the form of institutional statements and can be analysed in a linguistic way.

The outcomes of action situation are determined by resources, actors and institutions (Ostrom, 2009). There are seven types of institutions - position (the set of actors), boundary (positions), choice (the set of actions), aggregation (the level of control over the outcomes), information (available information), payoff (the costs and benefits of actions and outcomes) and scope (potential outcomes). The object of our study is the distributive effect of mandatory pension system. The effect is incarnated in the scope rules, because the distributive effect is a potential outcome. In other words, we will study only the scope rules.

Institutional statements can be analysed in the linguistic way (Crawford \& Ostrom, 1995). There are certain elements that constitute the institutional statement: $A$ (attributes), $D$ (deontic), $I$ (aim), $C$ (conditions) and $O$ (or else). For example, the grammar elements in the institutional statement 'The vendors are forbidden to sell the products of tobacco to the persons who do not reach the age of 18 at the moment of transaction, or they will lose the licence to sell the products of tobacco' are: 'vendors' as (A), 'forbidden' as (D), 'to sell the products of tobacco to the persons' as (I), 'who do not reach the age of 18 at the moment of transaction' as (C) and 'or they will lose the licence to sell the products of tobacco' as $(\mathrm{O})$. In the same way, we can analyse any institutional statement. The usage of grammar in detail is present in the paper by Basurto et al., (2009).

Now we can formulate the institutional statements that determine the redistributive effect of mandatory pension system. In a pension system with redistributive effect, the difference between contributions has to be greater than the difference between benefits (Skučienė \& Gataulinas, 2011). This kind of pension system is based on two general institutional statements:

- Who (A) have, must or could (D) make the contributions of amount $x$ (I) when and where (C) and what will happen if not $(\mathrm{O})$.

- Who (A) have, must or could (D) get the benefits of amount $x$ (I) when and where (C) and what will happen if not (O).

The institutions have a nested structure (Ostrom, 2009). In other words, the institutional statements are nested in other institutional statements. There are more general or more specific institutional statements.

The analysis of redistributive institutional statements in a pension system (one case) would give us deep understanding about the institutions and their interconnectedness, as it is demonstrated in the work of Basurto et al., (2009). However, in order to get the insights about the relationship between intentions and outcomes, we need more than one case (Ragin, 1989). Also, the cases have to be similar as much as possible, because the differences might be generated by other factors. Because of their similarity, the Baltic States fit the requirements well.

The institutional statements that govern the redistributive attribute of mandatory pension systems are coded in national legislature. In order to compare the elements of the institutional statements, we will use the data from MISSOC and national legislature.

\section{RESULTS}

In this part of the paper, we will compare the elements of institutional statements between the Baltic States. In the first part, we will analyse the elements of the first institutional statement - the contribution side. In the second part, we will compare the elements of the second institutional statement - the benefit side. 


\section{Who (A) Have, Must or Could (D) Make the Contributions of Amount X (I) When and Where (C) and What Will Happen If Not (O)}

\section{Attributes of contributors}

According to the national law in all the Baltic States, the contributors to the funds of pension system are employees and self-employed. However, there is confusion, because the employers make contributions on behalf of their employees. Thus, employers are also contributors.

\section{Deontic}

There are several logical operators connected with the action: Must, Could and Forbidden. In our case, to act is to make contributions. The modal verb must express the obligation to act in certain way, while the modal verb could express a voluntary action. The deontic aspects of institutions are presented in Table 3.

Tab.3: The deontic aspects of institutions in the Baltic States

\begin{tabular}{lllll}
\hline Variable & Estonia & Latvia & Lithuania \\
\hline First pillar & Must & Must & Must \\
& & Could (self-employed AND incomes below 4320 EUR per year) & \\
\hline Second pillar & $\begin{array}{l}\text { Must (born after 1983) } \\
\text { Forbidden (born before }\end{array}$ & $\begin{array}{l}\text { Must (born after 1971) Could (born from 1951 to 1971) } \\
\text { Could (self-employed AND incomes below 4320 EUR per year) }\end{array}$ & Could \\
& & & \\
\hline
\end{tabular}

Source: Author's calculations based on MISSOC data

As we can see, there are differences between countries. Making contributions to the first pillar of the mandatory pension system is obligatory for the inhabitants in all Baltic States. However, in Latvia, the nested institutional statement allows self-employed to choose either to participate or not, if the incomes are below 4320 EUR per year. The redistributive effect has only the first pillar or public pension. The possibility of choice allows self-employed not to make contributions to the system working by the principle pay as you go. And that can be interpreted as the loss of resources to finance the old age benefits. In this respect, the public pension is less distributive in Latvia.

The situation is different respectively to the second pillar. The inhabitants of Estonia must participate in the second pillar. Also, there is strict conditioning for those born before 1983 - it is forbidden to participate. However, there was a possibility to join the second pillar for those born before 1983 in 2002-2010. But the nested institution allows voluntary participation for the selfemployed with the incomes below 4320 EUR per year in Latvia. However, the participation in the second pillar is quasi-mandatory in Lithuania. The residents of Lithuania have a choice to participate or not to participate in the second pillar, and it is voluntary in this respect. However, there is no possibility to withdraw from the system (The participants were allowed to withdraw from the second pillar during one year in 2013 and it was a political decision), and in this respect, it looks like mandatory. The second pillar of pension system does not have the distributive effect among individuals. ${ }^{7}$ According to Orenstein $(2013,260)$, the occupational or personal pensions: reduce the role of the state, and dismantle the intra-and intergenerational social contract that has underpinned state-administered PAYG pension systems. Thus, the option not to participate in the second pillar or personal pension allows individuals to stay in more redistributive public pension system.

7 The pension systems can redistribute incomes from rich to poor and from poor to rich. The second pillar of pension system usually does not redistribute from rich to poor, but from poor to rich because of financial illiteracy of individluals. 


\section{Aim}

An action that is governed by the institution is to make contributions. There are three variables that describe the contributions to pension system: contribution rate, the ceilings of contribution and the flour of contribution. The values of the variables are presented in Table 4.

The high contribution rate expresses the pressures of demographic risks (but it is not attractive for the governments to increase the contribution rate), while the low contribution rates might show the intentions to increase the employment (Pensions at a glance, 2011). The mandatory contribution rate in most countries is proportional, but there might be differences in the contribution rate respectively to the incomes. It is argued that the ceilings of contribution will attract high level specialists with high incomes. The ceilings have negative effect on the redistributive effect of pension system. And on the contrary, the floors to contributions have positive effect on redistribution, because it differentiates the contribution rate or frees from contribution.

Tab.4: The contribution rate, ceilings and flour for the invalidity and old age pensions in the Baltic States

\begin{tabular}{llll}
\hline Variable & Estonia & Latvia & Lithuania \\
\hline Ceilings & No & Yes & Yes \\
\hline Floor & No & No & No \\
\hline Contribution employees & $22 \%$ of gross salary & $26.97 \%$ of gross salary & $28.3 \%$ of gross salary \\
\hline Self-employed and other & $22 \%$ & $\begin{array}{l}\text { For self-employed the contribution } \\
\text { is calculated on the basis of income, } \\
\text { exceptional and occupational activities. }\end{array}$ & $\begin{array}{l}\text { There are different rates of } \\
\text { contribution in respect to } \\
\text { from } 3 \% \text { to } 28.3 \% .\end{array}$ \\
\hline
\end{tabular}

Source: Author's calculations based on data from MISSOC for contribution ceilings and floor, Estonia.eu for contribution rates in Estonia, SODRA for contributions rates in Lithuania, Taxes in Europe Database v2 for contribution rates in Latvia.

The contribution ceilings are already introduced in Latvia and Lithuania. The mandatory pension systems have less distributive effect in comparison with Estonian pension system in this respect.

There is no contribution floor in the Baltic States.

The contribution rate is different in the Baltic States. The lowest contribution rate is in Estonia, while the highest in Lithuania. The contribution rate does not provide information about the possible redistributive effect. However, the differences in the contribution rate between different social groups provide information about the redistributive effect. The structure of contribution rates in Lithuania is complex. It varies from 3 to 28.3 per cent. If the differences in contribution rate are conditioned by the level of incomes (individuals with low incomes contribute less), then the system will have an equalizing effect. In the case of Lithuania, the differentiation of contribution rate is based on occupational groups, and that is clientelism. A similar situation is in Latvia. Only Estonia has the same contribution rates for self-employed and employees.

\section{Conditions}

The element conditions specify the conditions under which the action must and could be executed, or is forbidden. There are two general conditions: when and where. Generally, the inhabitants have to make contributions when they receive incomes. But there is also a possibility to make contributions on voluntary basis. According to the MISSOC data, there are no differences between Baltic States with respect to when. Also, the contributions to the mandatory pension system are collected by authorities in each Baltic State. 


\section{Or else}

The element or else specifies what will happen if the employee or self-employed will not make contributions to the pension funds. The employers and self-employed receive sanctions, if they do not make contributions.

\section{Who (A) Have, Must or Could (D) Get the Benefit of Amount X (I) When and Where (C) and What Will Happen If Not (O)}

\section{Attributes of recipients}

There are two general attributes or variables that describe the recipients of pensions (Table 5). The first one is the qualifying period. In order to get the pensions from the pension system, the individual has to have the qualifying period. The other attribute is retirement age. There are differences between men and women with respect to the retirement age.

Tab. 5: Qualifying period and retirement age in Baltic States (2016)

\begin{tabular}{llll}
\hline Variable & Estonia & Latvia & Lithuania \\
\hline Qualifying period & 15 years & 15 years & 15 years (30) \\
\hline $\begin{array}{l}\text { Retirement age and life } \\
\text { expectancy (2014) }\end{array}$ & M: $63(72.4)$ & M: 62 and $9(69.1)$ & M: 63 and 4 $(69.2)$ \\
\cline { 2 - 4 } & W: $63(81.9)$ & W: 62 and $9(79.4)$ & W: 61 and $8(80.1)$ \\
\hline
\end{tabular}

Source: Author's calculations based on MISSOC and Eurostat data (table [demo_mlexpec])

As we can see the qualifying period is the same in Baltic States - 15 years. In the case of Lithuania, 15 years is a minimal period and in order to get a 'full pension', the individuals need to have 30 years of insurance period.

However, there are differences in the retirement age. The retirement age is lifted because of saving and encouragement to work beyond the normal retirement age (Casey, 2004). Generally, it can be argued that pension systems are more redistributive when the difference between retirement age and life expectancy is bigger, because in that case they cover the greater share of population. According to this measurement, the highest coverage is in Estonia and thus, there is a greater redistribution.

As mentioned before, the qualifying period is more important than the contribution. The qualifying period is built from contributory and non-contributory periods of life. It can be stated that the pension systems that take into account more different cases of non-contributory periods have less strict requirements for pensions and as an outcome are more redistributive. The noncontributory periods of life taken into account are presented in Table 6.

There are the weight differences between the periods of life by the share of inhabitants it covers. For example, there are significantly less wives of diplomats or military residing abroad than individuals at the compulsory military service. By the sum of life periods that are taken into qualifying period, the leader is Latvia.

There is a standard age for retirement, but there are cases when it is possible to get early retirement. According to Casey (2004), the pension benefits are not high and in the case of early retirement, they are even lower in the Baltic States. It is not beneficial to take early retirement. Certain groups of residents are eligible for early retirement if they have certain attributes (Table 7).

As we can see, there are differences between countries. The strictest conditions for early retirement are in Lithuania, while the softest are in Estonia. Also Estonia and Latvia lead by the overall number of attributes that allow persons to take early retirement. The existence of special cases shows the legacy of Soviet Union (Müller, 2002; Cerami, 2011). 
Tab. 6: The non-contributory periods taken into account for qualifying period in the Baltic States

\begin{tabular}{llll}
\hline Variable & Estonia & Latvia & Lithuania \\
\hline Sickness & Yes & Yes & Yes \\
\hline Child care & Yes & Yes (child under 1.5) & No \\
\hline Maternity benefit & Yes & Yes & Yes \\
\hline Occupational rehabilitation & No & No & Yes \\
\hline Unemployment benefit & Yes & Yes & Yes \\
\hline Disability & No & Yes & No \\
\hline Period of receipt disability child allowance & No & Yes & Yes \\
\hline Adult care & No & No & No \\
\hline Wives of diplomats or military abroad & No & Yes & No \\
\hline Compulsory military service (until 1999) & Yes & Yes & Yes (until 1991) \\
\hline Full time studies & Yes (until 1999) & Yes (until 1991) & No \\
\hline Child care until child 8 years & Yes (until 1999) & Yes (until 1991) & Yes (until 1991) \\
\hline Period of political repression & No & Yes (until 1991) & Yes (until 1992) \\
\hline Working on a farm & Yes (until 1999) & No & Yes \\
\hline
\end{tabular}

Source: Author's calculations based on MISSOC data

Tab. 7: The attributes for early retirement in the Baltic States

\begin{tabular}{llll}
\hline Variable & Estonia & Latvia & Lithuania \\
\hline Contribution period & $\begin{array}{l}\text { Contribution period not less } \\
\text { than 15 years (3 years) }\end{array}$ & $\begin{array}{l}\text { Contribution period not less } \\
\text { than 30 years (2 years) }\end{array}$ & $\begin{array}{l}\text { 30 years of contribution AND no } \\
\text { other incomes (up to 5 years) }\end{array}$ \\
\hline Political prisoners & Yes & Yes & No \\
\hline Hard and hazardous occupations & Yes & Yes (before 1996) & No \\
\hline Certain professional groups & Yes & Yes & No \\
\hline Raised children & Yes & Yes & No \\
\hline Disability & Yes & Yes & No \\
\hline
\end{tabular}

Source: Author's calculations based on MISSOC data

\section{Deontic}

The deontic is not specified for the receiver of pension benefit. In other words, it is not said that an individual must, have or can take the pension benefits. Thus, there are no differences between Baltic States with respect to this element. 


\section{Aim}

If the individual possesses the required attributes, then he will receive the old age pension benefits. The calculation of the benefits is based on specific institution - benefit calculation rule or formula. The distributional effects of benefit calculation rules in Baltic States are presented in Figure 1.

Fig.1: The distributional effects of benefit calculation rules in Baltic States

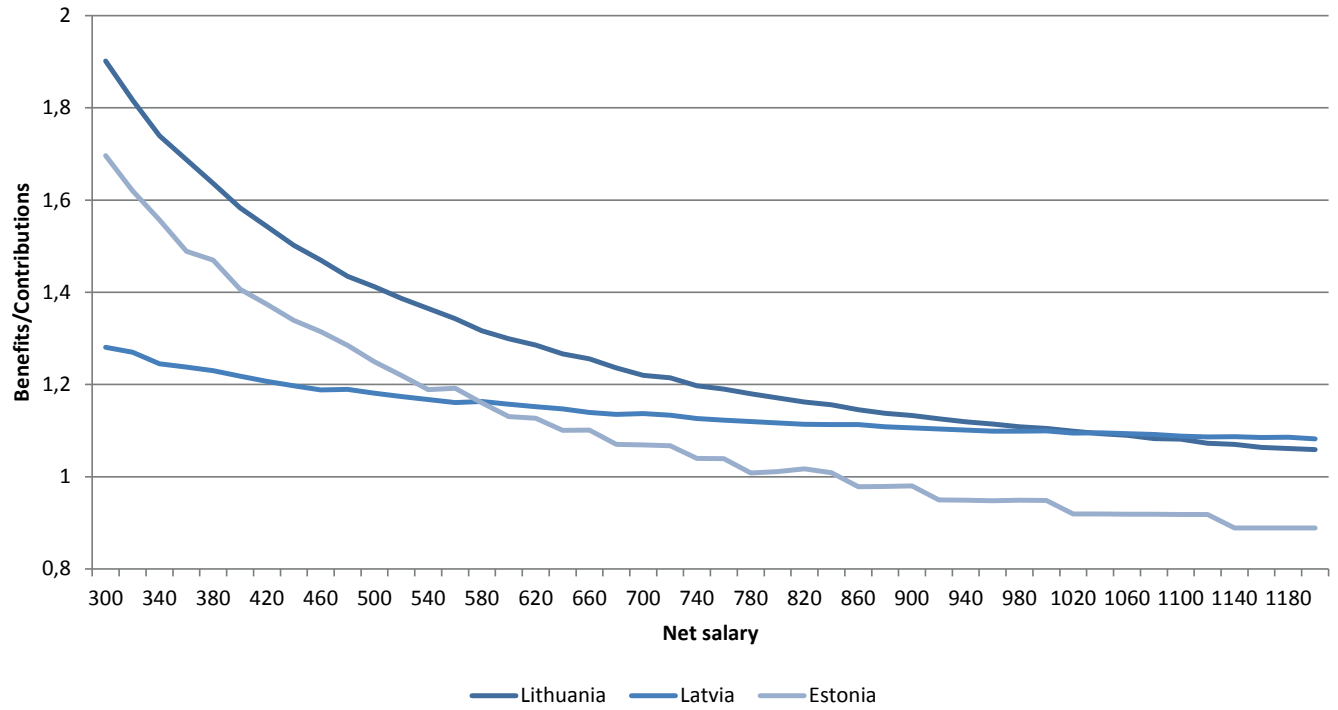

Source: Author's calculations based on data from AB SEB bankas for old-age pension benefits and TAX LT for contributions in Lithuania, AS SEB Pank for old-age pension benefits and Trinity Capital for contributions in Estonia, SEB Finance Centre for old age pension benefits and Trinity Capital for contributions in Latvia.

The curves show the change of ratio between old age pension benefits and contributions to the mandatory pension system. The contributions to the mandatory pension (first and second pillar) system were calculated using tax calculators. The ratio was calculated for individuals who are 24 years old at the moment and are participating in first (social insurance) and second (funded) pension pillars. The benefits were calculated using pension calculators from SEB Bank for each country. The benefits from the first pillar are calculated under the assumption that a person is full-time working and paying taxes. The benefits from the second pillar are calculated under the assumptions that a person will make contributions and there is a certain level of return on investment. Also, the calculations are adjusted to life expectancy, inflation rate and wage growth. The vertical axis presents the values of ratio and horizontal axis - the values of net salary. As we can see, the ratio diminishes as the net salary increases in all Baltic States. However, there are differences. The lowest distributional effect of pension benefit calculation rule is in Latvia, while it is quite the same in Lithuania and Estonia.

The calculation of public pension benefit is based on different factors (Casey, 2004). In Estonia, the amount of benefit depends on insurance period and earning relative to national average. In Latvia, the amount of benefit depends on earning, the period of contribution, retirement age and life expectancy. In Lithuania, the basic pension depends on the period of insurance, while the supplementary part depends on earnings.

\section{Supplements}

The amount of pension might be increased by supplements. There are different social groups that are granted with the special status. In Latvia and Estonia, there are supplements to the pension benefits, while there are no supplements in Lithuania (Table 8). 
Tab. 8: The supplements for pension benefits in Baltic States

\begin{tabular}{llll}
\hline Variable & Estonia & Latvia & Lithuania \\
\hline Retired before 2012 & No & Yes & No \\
\hline Participants of war & Yes & No & No \\
\hline Hazardous occupation & Yes & No & No \\
\hline Child care & Yes & No & No \\
\hline
\end{tabular}

Source: Author's calculations based on MISSOC data

Tab. 9: The summary of results

\begin{tabular}{llll}
\hline Elements & Estonia & Latvia & Lithuania \\
\hline Deontic (Contribution) & 2 & 3 & 1 \\
\hline Aim (Contribution) & 1 & 2 & 2 \\
\hline Attributes (Benefit) & $1,2,1$ & $3,1,2$ & $2,3,3$ \\
\hline Aim (Benefit) & $1,2,2,1$ & $2,3,3,1$ & $1,1,1,2$ \\
\hline Overall & $5 * 1 ; 4 * 2$ & $2 * 1 ; 3 * 2 ; 3 * 3$ & $4 * 1 ; 3 * 2 ; 2 * 3$ \\
\hline
\end{tabular}

Source: Author

As we can see from Table 8, there are differences in pension supplements between Estonia and Latvia. It can be stated that the supplement retired before 2012 covers the higher number of inhabitants than the supplements - participants of war, hazardous occupation and child care all together.

\section{Taxation}

Pension benefits are incomes and they can be taxed. However, there are differences in the attitude towards the taxation of social benefits in Baltic States. According to MISSOC, the old age pension benefits are under taxation in Estonia and Latvia. However, the benefits are not taxed in Lithuania. Also, there is a difference between Estonia and Latvia with respect to the share of population whose benefits are taxed. In Estonia, all pension benefits are taxed, while in Latvia, the pension benefits are only taxed if they were appointed after 1996. However, the tax exemption limit for pensioners (after 1996) is 235 EUR per month in Latvia while in Estonia it is 354. Tax exemption limit is higher in Estonia in relation to average pension, while in Latvia it is lower. It means that pensioners in Estonia pay less income tax, than their counterparts in Latvia.

\section{Indexation}

Due to macroeconomic fluctuations, the value of pension benefits change and the adjustments have to be done. Also, the growth of national economies implies the increase of pension benefit in order to provide decent life conditions. According to MISSOC, the pension benefits are indexed in Estonia and Latvia. There is no indexation of pension benefits in Lithuania. However, the value of pension benefits can be changed by the decision of politicians in Lithuania. 


\section{Conditions}

The element conditions specify the conditions under which the action must and could be executed, or is forbidden. There are two general conditions: when and where. The condition where is the same in all Baltic States. In order to receive the pension benefits, the inhabitants have to express their will to the administrators of pension systems. Also, the conditions when are specified as a voluntary decisions.

\section{Or else}

There are no sanctions for not taking the pension benefits in Baltic States.

\section{DISCUSSION AND CONCLUSIONS}

In this paper, we compared the institutional statements that govern the distributive effect of mandatory pension systems in the Baltic States. The summary of results is presented in Table 9.

The table presents the elements of institutional statements where the differences between Baltic States were found. As we can see, there were differences in two elements of the first institutional statement (marked with contribution) and there were differences in two elements of the second institutional statement (marked with benefit). The numbers in the rows represent the rankings of distributive effect in certain elements. The value of 1 signifies the highest distributive effect in relation to other countries. The last row expresses the results of rankings calculation. Because rankings are measured in the scale of ranks, there is no reason to apply mathematical operators. But it is possible to compare the results by comparison of sums of each value. We can see that the highest number of values 1 is in Estonia. The number of values 2 is the same in Latvia and Lithuania and the number of values 2 is highest in Latvia. However, Estonia has no values 3. The conclusion is that the old age pension system is more redistributive in Estonia than in other Baltic States. But we have to remember that pension system of Lithuania has the greatest factual distributive effect (Table 2). Thus, we can state that the intentions are not the same as the outcomes in the mandatory pension systems of the Baltic States.

It is important to acknowledge that our object of study was mandatory pension system. The differences that are revealed between the Baltic States represent not the differences of overall welfare state, but the differences in mandatory pension system.

\section{ACKNOWLEDGEMENTS}

This article was supported by Research Council of Lithuania grant GER - 007/2015. The authors would like to thank two anonymous reviewers for their valuable comments.

\section{REFERENCES}

Aidukaite, J. (2006). The formation of social insurance institutions of the Baltic States in the post-socialist era. Journal of European Social Policy, 16(3), 259-270.

Atkinson, A. B. (2003). Income inequality in OECD countries: Data and explanations. CESifo Economic Studies, 49(4), 479-513.

Barr, N. A. (1998). The economics of the welfare state. Stanford University Press.

Basurto, X., Kingsley, G., McQueen, K., Smith, M., \& Weible, C. M. (2009). A systematic approach to institutional analysis: applying Crawford and Ostrom's grammar. Political Research Quarterly, 63(3), 523-537.

Casey, B. H. (2004). Pension Reform in the Baltic States: Convergence with 'Europe' or with' the World'? International Social Security Review, $57(1), 19-45$.
Cerami, A. (2011). Ageing and the politics of pension reforms in Central Europe, South-Eastern Europe and the Baltic States. International Journal of Social Welfare, 20(4), 331-343.

Clement, F., \& Amezaga, J. M. (2009). Afforestation and forestry land allocation in northern Vietnam: analysing the gap between policy intentions and outcomes. Land Use Policy, 26(2), 458-470.

Cranmer, S. (2006). Enhancing graduate employability: best intentions and mixed outcomes. Studies in Higher Education, 31(2), 169-184.

Crawford, S. E. \& Ostrom, E. (1995).A grammar of institutions. American Political Science Review, 89(03), 582-600.

Eurostat (2016).EU statistics on income and living conditions (EU-SILC) methodology-distribution of incomes. Retrieved from: http://ec.europa. 
eu/eurostat/statistics-explained/index.php/EU_statistics_on_income_ and_living_conditions_\%28EU-SILC\%29_methodology_-_distribution_ of_income

Gillwald, A. (2005). Good intentions, poor outcomes: Telecommunications reform in South Africa. Telecommunications Policy, 29(7), 469-491.

Hwang, S. J. (2016). Public Pensions as the Great Equalizer? Decomposition of Old-Age Income Inequality in South Korea, 19982010. Journal of aging \& social policy, 28(2), 81-97.

Lazutka, R. (2003). Gyventojų pajamy nelygybè [Population's income inequality]. Filosofija. Sociologija, 2, 22-29.

Lazutka, R. (2007). Pensijy sistemy raida Lietuvoje [Development of pension schemes in Lithuania]. Filosofija. Sociologija, 18(2), 64-80.

Le Grand, J. (2003). Motivation, agency, and public policy: of knights and knaves, pawns and queens. Oxford University Press.

Lithuania Department of Statistics (2015). Economic and social development in Lithuania, Latvia and Estonia. Retrieved from:https:// www.stat.gov.lt/services-portlet/pub-edition-file?id=17886

Mahoney, J. \& Thelen, K. (2009). A theory of gradual institutional change. In Mahoney, J. \& Thelen, K. (Eds.) Explaining institutional change: Ambiguity, agency, and power (pp. 1-37). Cambridge University Press.

Mattil, B. (2006). Pensions Systems. Sustainability and Distributional Effects in Germany and the United Kingdom. Physica-Verlag Heidelberg.

Müller, K. (2002) Old-age security in the Baltics: legacy, early reforms and recent trends. Europe-Asia Studies, 54(5), 725-748.

Neckerman, K. M. \& Torche, F. (2007). Inequality: Causes and consequences. Annu. Rev. Sociol., 33, 335-357.

Norkus, Z. (2012). On Baltic Slovenia and Adriatic Lithuania: a qualitative comparative analysis of patterns in post-communist transformation. Central European University Press.

OECD. (2011). Pensions at a Glance 2011: Retirement-income Systems in $O E C D$ and $G_{20}$ Countries. Organisation for Economic Co-operation and Development.

Orenstein, M. A. (2013). Pension privatization: evolution of a paradigm. Governance, 26(2), 259-281.

Ostrom, E. (2009). Understanding institutional diversity. Princeton university press.

\section{OTHER DATA SOURCES}

AB SEB bankas. (2016). Pension calculator for Lithuania. Retrieved from: https://www.seb.It/skaiciuokles/pensiju-skaiciuokle

AS SEB Pank.(2016).Pension plan. Retrieved from: https://www.seb.ee/ ip/ipank.p?sesskey=\&act=PENSIONPLAN\&lang=ENG\&frnam $=$ X\&unet menuhigh=

Central Statistical Bureau of Latvia (2016). Database. Retrieved from: http://www.csb.gov.Iv/en
Ostrom, E. (2011). Background on the institutional analysis and development framework. Policy Studies Journal, 39(1), 7-27.

Philipov, D. (2009). Fertility intentions and outcomes: the role of policies to close the gap. European Journal of Population/Revue européenne de Démographie, 25(4), 355-361.

Ragin, C. C. (1989). The comparative method: Moving beyond qualitative and quantitative strategies. University of California Press.

Rajevska, O. (2013). Equity criterion in pension system assessment and its manifestation in Estonian and Latvian pension schemes. Journal of Economic and Management Research, 2, 118-130.

Rajevska, O. \&Rajevska, F. (2014). Notional Defined Contribution pension scheme experience in Latvia: some lessons. Studia Humanistyczne AGH, 13(4), 185-197.

Rajevska, O. (2015). Sustainability of pension systems in the Baltic States. Entrepreneurial Business and Economic Review, 3(4), 139-153.

Rajevska, O. (2016). Theoretical old-age pension benefits and replacement rates in the Baltic States: A retrospective simulation. Economics and Business, 28, 13-19.

Reynolds, M. \& Smolensky, E. (1977). Public expenditures, taxes, and the distribution of income: The United States, 1950, 1961, 1970. Academic Press.

Skučienè, D. \& Gataūlinas, A. (2011). Lietuvos socialinio draudimo kompensuojamoji gerovè lyginant su ES šalimis [Compensatory welfare of Lithuanian social insurance system among EU member states]. Socialinis darbas, (02), 301-314.

Skučienè, D. (2008). Pajamy nelygybè Lietuvoje [Income inequality in Lithuania]. Filosofija. Sociologija, 4, 22-33.

Statistics Estonia (2016). Statistical yearbook of Estonia. Statistics Estonia, Tallinn.

Whitehouse, E. (2004). Comparing the new pension systems of the Baltic States Pension Reform in the Baltic Countries, Private Pensions Series, (5), 25-58.

Žalimienè, L., \& Dunajevas, E. (2014). Lietuvos socialinès paramos struktūra kliento autonomijos - paternalizmo požiuriu [Structure of social assistance in Lithuania from the perspective of the client's autonomy and paternalism]. Socialinis Darbas: Patirtis ir Metodai, 14(2), 37-54.

Eurostat (2016). Database. Retrieved from: http://ec.europa.eu/eurostat/ data/database

MISSOC (2016). Database. Retrieved from: http://www.missoc.org/ INFORMATIONBASE/informationBase.jsp

SEB finanšu centrs. (2016). Pensijas prognozes kalkulators [Pension calculator for Latvia]. Retrieved from:http://i.seb.lv/lv/private/ services/uzkrajumi-un-ieguldijumi/ilgtermina-pensijas-uzkrajumi-unapdrosinasana/pensijas-uzkrajumi/pensijas-prognozes-kalkulators/ 
SODRA.(2016). Database. Retrieved from: http://atvira.sodra.It/en-eur/

TAX LT. (2016). Atlyginimy ir mokesčiy skaičivokle [Tax calculator for Lithuania]. Retrieved from: http://www.tax.It/skaiciuokles/atlyginimo_ ir_mokesciu_skaiciuokle

Taxes in Europe Database v2. (2016). Database. Retrieved from: http:// ec.europa.eu/taxation_customs/tedb/taxSearch.html

Trinity Capital (2016). Tax calculator for Latvia and Estonia. Retrieved from: http://www.calkoo.com/?lang=3\&page=1 